\title{
Strengthening the Effectiveness of International Criminal Law through the Principle of Legality
}

1

\begin{abstract}
The principle of legality is an integral part of international criminal law (ICL). International criminal courts and tribunals (ICCTs) have applied a 'soft' version of legality that has seldom operated as a meaningful curb upon their decisions. This article argues that, as the field of ICL continues to mature and develop, its legitimacy and effectiveness would be enhanced if ICCTs applied a stricter version of legality. It explores the constituent elements of the principle- the doctrines of non-retroactivity, specificity, foreseeability and strict constructionexamining how they have been applied in the past and suggesting ways to apply them in the future. The article argues that ICCTs should strive to set the gold standard when it comes to adherence to the principle of legality. This has the benefit of better protecting the rights of the accused, thereby ensuring a more effective and legitimate system of law.
\end{abstract}

\section{Keywords}

criminal law; legality; legitimacy; effectiveness

\section{Introduction}

International criminal law (ICL) is replete with contradictions. One the one hand, it purports to be criminal law, with the accordant expectations to abide by the principles and rules that apply within that field. On the other hand, it is imbued with unique elements marking it out from 'ordinary' criminal law, with its high aspirations to punish those responsible for 'the most serious crimes of concern to the international community as a whole' and its determination 'to put an end to impunity for the perpetrators of these crimes'. ${ }^{2}$ The field of international criminal justice is perpetually being pulled in different directions: common law traditions are pitted against civil law traditions; positivist approaches against natural law approaches; ${ }^{3}$ the rights of the accused against the rights of victims. ${ }^{4}$ It is engaged in a

\footnotetext{
1

${ }^{2}$ Preamble to the Statute of the International Criminal Court, 1998 ('ICC Statute').

${ }^{3}$ Noora Arajärvi, 'Between Lex Lata and Lex Ferenda? Customary International (Criminal) Law and the Principle of Legality’, 15 Tilburg Law Review (2010-2011) 163.

${ }^{4}$ Darryl Robinson, 'The Identity Crisis of International Criminal Law', 21 Leiden Journal of International Criminal Law (2008) 925-963; Sergey Vasiliev, 'The Making of International Criminal Law', in C. Brölmann and Y. Radi (eds.), Research Handbook on the Theory and Practice of International Lawmaking (Edward Elgar, Cheltenham, 2016).
} 
perennial juggling of human rights, transitional justice and domestic criminal law aspirations. ${ }^{5}$ As a consequence, it has been described as suffering from an 'identity crisis ${ }^{6}$ and as being a 'paradox field that is torn apart by conflicting philosophies, aspirations, and methodologies."

Nestled in the midst of these paradoxes, lies the principle of legality. Legality, often referred to by its Latin maxim, nullum crimen sine lege, nulla poena sine lege, exists in some form or other within most domestic legal systems. ${ }^{8}$ It requires that criminal liability and punishment be based upon prior legislative enactment of a prohibition that is expressed with adequate precision and clarity. ${ }^{9}$ Legality has been described as a 'cornerstone' of ICL and found to be a jus cogens norm, ${ }^{10}$ and yet the field of international criminal justice has not had an easy relationship with the principle. Since its inception, ICL has left itself open to criticisms that it does not pay sufficient heed to the requirements of legality, that it suffers from a 'legality deficit', ${ }^{11}$ and this, in turn, has had an effect upon the legitimacy of the field. ${ }^{12}$

Although ICL has generally professed compliance with the principle of legality, whether this is in fact the case, or simply lip-service, is open to debate. The principle has rarely operated as a curb upon the decisions made by ICCTs in any meaningful way. Rather, a 'soft' version of legality has been applied. This article argues that the time has come for the doctrine of legality to step forward and play a stronger, more defining role in international criminal justice. Legality is a useful and necessary tool in ensuring the effectiveness of ICL in protecting the rights of the accused and in achieving legitimacy within its decision making,

The paper begins by briefly discussing the origins of the principle of legality and what it entails. It then examines how international criminal courts and tribunals (ICCTs) have applied the different elements of the principle, namely those of non-retroactivity, specificity, foreseeability and strict construction. Finally, the paper discusses what the future holds for the principle of legality in ICL.

\footnotetext{
${ }^{5}$ Allison Marston Danner and Jenny S. Martinez, 'Guilty Associations: Joint Criminal Enterprise, Command Responsibility and the Development of International Criminal Law', 93(1) California Law Review (2005) 75-169, p. 78.

${ }^{6}$ Robinson, supra note 4.

${ }^{7}$ Vasiliev, supra note 4, p. 363.

${ }^{8}$ Kenneth S. Gallant, The Principle of Legality in International and Comparative Criminal Law (Cambridge University Press, Cambridge, 2009), pp. 11-12; Bruce Broomhall, 'Article 22: Nullum Crimen Sine Lege' in Otto Triffterer, Commentary on the Rome Statute of the International Criminal Court- Observers' Notes, Article by Article (C.h. Beck, Hart, Nomos, Munich, $2^{\text {nd }}$ edition, 2008), pp. 720-722; M. Cherif Bassiouni, 'Principles of Legality in International and Comparative Law, in M. Cherif Bassiouni, Editor, International Criminal Law, Volume 1: Sources, Subjects and Contents (Martinus Nijhoff Publishers, Leiden, 2008), pp. 76-84.

9 Paul H. Robinson, 'Fair Notice and Fair Adjudication: Two Kinds of Legality', 154(2), University of Pennsylvania Law Review (2005) 335-398, p. 336.

${ }^{10}$ STL, Prosecutor v. Salim Jamil Ayyash et al, Case No. STL-11-01/I/AC/R176bis, Appeals Chamber, Interlocutory Decision on the Applicable Law: Terrorism, Conspiracy, Homicide, Perpetration, Cumulative Charging, 16 February 2011, para. 76.

${ }^{11}$ George P. Fletcher and Jens David Ohlin, 'Reclaiming Fundamental Principles of Criminal Law in the Darfur Case' 3 Journal of International Criminal Justice (2005) 539-561, p. 551.

${ }^{12}$ Broomhall, supra note 8, p. 716; David Luban, 'Fairness to Rightness: Jurisdiction, Legality, and the Legitimacy of International Criminal Law’, Georgetown Faculty Working Papers, July 2008.
} 


\section{What Does the Principle of Legality Entail?}

Conventional wisdom has it that the principle of legality evolved during the enlightenment as a means of curbing the power of the state. ${ }^{13}$ Liszt describes the maxims of nullum crimen sine lege and nulla poena sine lege as being:

the citizen's bulwark against the State's omnipotence; they protect the individual against the ruthless power of the majority, against Leviathan. However paradoxical it may sound, the Criminal Code is the criminal's Magna Charta. It certifies his right to be punished only in accordance with the statutory requirements and only within the statutory limits. ${ }^{14}$

Several rationales lie behind the principle, including those of preserving authority to criminalise conduct to the legislature rather than judges; providing fair notice by giving addressees of the law an opportunity to ascertain what conduct is prohibited; deterring through the threat of punishment; increasing uniformity in the application of the law; and reducing the potential for abuse of discretion, for example by discouraging arbitrary convictions or arrests. ${ }^{15}$

Legality is comprised of two components, that of nulla crimen sine lege (that nothing is a crime except under previous existing law) and that of nullum poena sine lege (that no punishment may be imposed except under previous existing law). This paper is solely concerned with the former aspect. The nulla crimen principle is, in turn, comprised of different doctrines, ${ }^{16}$ not all of which apply in all legal systems, ${ }^{17}$ and some of which are applied differently within different legal systems. ${ }^{18}$ These doctrines comprise, firstly, a prohibition on the retroactive application of the law. Secondly, a requirement of specificity, entailing that the law be as specific and detailed as possible, and clearly indicate what conduct is prohibited. Thirdly, a requirement of foreseeability, meaning that the law be accessible to alleged perpetrators and that fair notice be given as to what conduct is open to prosecution. Fourthly, a requirement of strict interpretation, that definitions of crimes be strictly construed and not be extended by analogy; and that in cases of ambiguity, the in dubio pro reo rule should apply, meaning that the interpretation most favourable to the accused should be adopted.

In addition to being an important component of most national legal systems, ${ }^{19}$ the principle of legality is included within several human rights treaties ${ }^{20}$ and the central aspects

\footnotetext{
${ }^{13}$ For a discussion on the origins of the principle, see Jerome Hall, 'Nulla Poena Sine Lege,' 47(2) The Yale Law Journal 165.

${ }^{14}$ Franz von Liszt, 'Die deterministischen Gegner der Zweckstrafe', 13 Die gesamte Strafrechtswissenschaft (1983) 325-370, as translated in Franz von Liszt, 'The Rationale for the Nullum Crimen Principle', 5 Journal of International Criminal Justice (2007) 1109-1013, p. 1010.

${ }^{15}$ Robinson, supra note 9, pp. 363-367.

${ }^{16}$ See Veeber v. Estonia (No. 2), Application no, 45771/99, 21 January 2003 and Puhk v. Estonia, Application no, 55103/00, 10 February 2004, para. 25.

${ }^{17}$ For a list of different rules see Gallant, supra note 8, pp. 11-12.

${ }^{18}$ Thus, for example, elements of the principle of legality are applied differently in common law systems than they are in civil law systems, see $S W v$. United Kingdom, 22 November 1995, A335-B and CR v. United Kingdom, 22 November 1995, A335-C. Also see Antonio Cassese, 'Nullum Crimen Sine Lege' in Antonio Cassese (Editor), The Oxford Companion to International Criminal Justice (Oxford University Press, Oxford, 2013), p. 438.

${ }^{19}$ See Gallant, supra note 8, Chapter 5.

${ }^{20}$ Article 11, Universal Declaration of Human Rights; Article 15, International Covenant on Civil and Political Rights. For regional agreements, see Article 7, European Convention on Human Rights, Article 9, American Convention on Human Rights and Article 7(2), African Charter of Human and People's Rights. Also see Article 99, Geneva Convention Relative to the Treatment of Prisoners of War, 1949 and Article 6(c), Protocol Additional
} 
of the principle have been confirmed as being customary international law. ${ }^{21}$ Thus, the principle of legality is firmly embedded within both domestic and international law. I will now consider how the key elements of nullum crimen sine lege, namely non-retroactivity, specificity, foreseeability and strict construction, have been applied within the field of ICL.

\section{The Doctrine of Non-retroactivity}

Since its very beginnings following the creation of the International Military Tribunal at Nuremberg ('IMT') in the ashes of the Second World War, ICL has faced accusations that its courts and tribunals have applied retroactive law. During the post-war period, there was little in the way of precedent for the drafters of the Charter of the International Military Tribunal ('IMT Charter') and other post war instruments to draw upon. ${ }^{22}$ The IMT Charter granted the tribunal jurisdiction over three classes of crime: war crimes, crimes against humanity and crimes against peace. ${ }^{23}$ All three generated criticism that they violated the principle of legality, albeit to different degrees.

Although defence counsel at the IMT raised legality claims concerning war crimes, ${ }^{24}$ the question of whether this constituted retroactive law was not a pressing issue. ${ }^{25}$ By the time of the Second World War, it was generally accepted that persons who violated the 'laws and customs of war' could be held criminally responsible for doing so. ${ }^{26}$ The IMT was able to refer to treaty law to support the position that violations of certain provisions of the laws of armed conflict constituted crimes for which the guilty individuals were punishable. ${ }^{27}$

It was a different matter as regards crimes against peace and crimes against humanity, where there was little in the way of precedent for the tribunal to draw upon. ${ }^{28}$ During the trial process, counsel for the defendants focused their arguments on the retroactivity of crimes against peace. They lodged a pre-trial motion asserting that it is a fundamental principle of both international and domestic law that there can be no punishment of a crime without pre-

\footnotetext{
to the Geneva Conventions of 12 August 1949 and relating to the Protection of Victims of Non-International Armed Conflicts, 1977.

${ }^{21}$ Gallant, supra note 8, p. 352 and see Chapter 7, generally.

${ }^{22}$ See Charter of the International Military Tribunal for the Far East, 1946 and Control Council Law No. 10, Punishment of Persons Guilty of War Crimes, Crimes against Peace and against Humanity, 20 December 1945.

${ }^{23}$ Article 6, IMT Charter.

${ }^{24}$ Gallant writes that among the defence counsel 'Only a few directly attacked the legality of prosecutions for traditional war crimes'. Gallant, supra note 8, p. 105 and see pp. 117-119.

${ }^{25}$ Christian Tomuschat, 'The Legacy of Nuremberg', 4 Journal of International Criminal Justice, (2006) 830-844, p. 834.

${ }^{26}$ Minutes of Conference Session, July 23 1945, Report of Robert H. Jackson United States Representative to the International Conference on Military Tribunals, London 1945 (Washington: United States Department of State, 1949), p. 331.

${ }^{27}$ Trial of the Major War Criminals before the International Military Tribunal, Nuremberg, 14 November 19451 October 1946 (1948), Vol. 22, p. 497.

${ }^{28}$ There was some earlier precedent concerning crimes against humanity, Schabas argues that the notion of crimes against humanity was widespread from at least the middle of the Eighteenth century, see William Schabas, Unimaginable Atrocities: Justice Politics and Rights at the War Crimes Tribunals (Oxford University Press, Oxford, 2012) pp. 51-53. Also see Egon Schwelb, 'Crimes against Humanity' 23 The British Yearbook of International Law, 178 (1946), pp. 180-182.
} 
existing law, and that therefore crimes against peace and other principles of a penal character in the Charter were contrary to the principle of nulla crimen sine lege. ${ }^{29}$

In its Judgment, the IMT paid most consideration to the challenge of ex post facto legislation in the context of the crime of aggression. ${ }^{30}$ It found that the Charter 'is the expression of international law existing at the time of its creation', and as the Charter made the planning or waging of a war of aggression or a war in violation of international treaties a crime, it was not strictly necessary for the tribunal to consider whether it was a crime prior to the London Agreement. ${ }^{31}$ Nevertheless, it chose to address the defendants' challenge in any case, famously finding that 'the maxim nullum crimen sine lege is not a limitation of sovereignty, but is in general a principle of justice'. ${ }^{32}$ It continued that the Nazi leaders 'must have known that they were acting in defiance of all international law when in complete deliberation they carried out the designs of invasion and aggression. ${ }^{33}$ Thus, the judges, while acknowledging the existence of the principle of legality, were nevertheless of the view that it could be set aside in the event that higher-ranking principles of natural justice so required. ${ }^{34}$

The Nuremberg Judgment has been subject to criticism over the intervening decades for many different reasons, ${ }^{35}$ not least its failure to comply with the principle of legality. Gallant, for example, argues that the entire Nuremberg process, from the London Conference through to the Nuremberg Judgment, was 'shot through with ambiguities on the issues of legality and retroactivity of criminal law. ${ }^{36}$ The choice of the IMT to advocate a doctrine of substantive justice ${ }^{37}$ rather than adhere to a positivist application of the law proved acceptable to legal naturalists, who agreed that this approach was warranted, ${ }^{38}$ and that the doctrine of

\footnotetext{
${ }^{29}$ They argued that "no sovereign power has made aggressive war a crime at the time that the alleged criminal acts were committed, that no statute has defined aggressive war, that no penalty has been fixed for its commission, and no court has been created to try and punish offenders.' Trial of the Major War Criminals before the International Military Tribunal, Nuremberg, 14 November 1945- 1 October 1946 (1948), Vol. 22, p. 462.

${ }^{30}$ The concept of crimes against humanity was interpreted strictly by the Tribunal which required that it be charged in connection with one of the other crimes under their jurisdiction, see IMT Judgment, supra note 27, p. 493 and Beth van Schaak, 'Crimen Sine Lege: Judicial Lawmaking at the Intersection of Law and Morals', 97 The Georgetown Law Journal (2008-2009) 119, pp. 129-130.

${ }^{31}$ IMT Judgment, supra note 27, p. 461.

32 Ibid., p. 462.

33 Ibid., p. 462.

${ }^{34}$ Vasiliev, supra note 4, p. 368. Other cases in the post war period also took the view that substantive justice trumped a strict application of the principle of legality, see Judgment of the International Military Tribunal for the Far East, 4 November 1948 in J. Pritchard and SM Zaide (editors), The Tokyo War Crimes Trial, Vol. XXII, Proceedings in Chambers (Garland, Shrewsbury MA, 1981) 48439; and see A. Cassese, P. Gaeta et al (eds.), Cassese's International Criminal Law, (Oxford University Press, Oxford, 2013), pp. 25-26 for a discussion of other relevant cases.

${ }^{35}$ For summaries of these criticisms see Kevin R. Chaney, 'Pitfalls and Imperatives: Applying the Lessons of Nuremberg to the Yugoslav War Crimes Trials',14(1) Dickinson Journal of International Law 58, pp. 70-81 and Van Schaak, supra note 30, 125-134.

${ }^{36}$ Gallant, supra note 8, p. 155.

${ }^{37}$ See Cassese, supra note 34, p. 25.

${ }^{38}$ One contemporary supporter of this view was Hans Kelsen, who argued that 'Justice required the punishment of these men, in spite of the fact that under positive law they were not punishable at the time they performed the acts made punishable with retroactive force. In case two postulates of justice are in conflict with each other, the higher one prevails; and to punish those who were morally responsible for the international crime of the Second World War may certainly be considered as more important than to comply with the rather relative rule against $e x$ post facto laws, open to so many exceptions.' Hans Kelsen, 'Will the Judgment in the Nuremberg Trial Constitute a Precedent in International Law?' 1 International Law Quarterly (1947) 153, p. 165.
} 
legality could be trumped by considerations of justice. ${ }^{39}$ However, for those who advocated a positivist approach, the position taken by the IMT was unacceptable.

Despite any misgivings, the findings of the IMT were followed by the Tokyo tribunal, ${ }^{40}$ as well as being endorsed by the UN General Assembly ${ }^{41}$ and by subsequent human rights treaties. ${ }^{42}$ The substantive law emanating from the Nuremberg process and the other post-Second World War tribunals was given further legitimacy when it was relied upon by other ICCTs.

Adherence to the principle of non-retroactivity remained a live issue before the ad hoc tribunals. The Statutes of the International Criminal Tribunal for the former Yugoslavia ('ICTY') ${ }^{43}$ and the International Criminal Tribunal for Rwanda ('ICTR') ${ }^{44}$ were created after many of the crimes over which they had jurisdiction had been committed, raising the spectre of retroactive law. In his report on the establishment of the ICTY, the UN Secretary General addressed the legality issue. He was careful to explain that by assigning the task of prosecuting those most responsible for serious violations of international humanitarian law ('IHL'), the Security Council would not be creating new crimes, but would rather be applying existing IHL in the form of conventional and customary law. ${ }^{45}$ He stated that the tribunal should apply rules of IHL that were 'beyond any doubt part of customary law'. ${ }^{6}$

Nevertheless, despite the reference to the principle of legality within the report, no mention of it was made within the Statute itself, and it was left to the tribunal's judges to outline the parameters of the principle within the jurisprudence of the court.

By the time the ICTR Statute was adopted a mere 18 months later, a more relaxed attitude was being taken towards the substantive law over which the new tribunal would have jurisdiction. ${ }^{47}$ The UN Security Council 'elected to take a more expansive approach to the choice of the applicable law than had been taken regarding the one underlying the Statute of the Yugoslav Tribunal. ${ }^{48}$ It opted to include within the subject-matter jurisdiction of the ICTR international instruments 'regardless of whether they were considered part of customary international law or whether they have customarily entailed the individual criminal responsibility of the perpetrator of the crime. ${ }^{49}$ The Report acknowledged that Article 4 of the Statute pertaining to war crimes 'includes violations of Additional Protocol II, which as a whole, has not yet been universally recognized as part of customary international law, and for

\footnotetext{
${ }^{39}$ Luban, supra note 12, p. 20.

${ }^{40}$ Pritchard and Zaide, supra note 34, 48439.

${ }^{41}$ United Nations General Assembly Resolution 95(1), Affirmation of the Principles of International Law recognized by the Charter of the Nürnberg Tribunal, Fifty fifth plenary meeting, 11 December 1946.

${ }^{42}$ See supra note 20. Also see William A. Schabas, 'Synergy or Fragmentation? International Criminal Law and the European Convention on Human Rights', 9 Journal of International Criminal Justice (2011) 609-632, pp. 609610.

${ }^{43}$ Statute of the International Criminal Tribunal for the former Yugoslavia, 1993 (ICTY Statute).

${ }^{44}$ Statute of the International Criminal Tribunal for Rwanda, 1994 (ICTR Statute).

${ }^{45}$ Report of the Secretary-General Pursuant to Paragraph 2 of Security Council Resolution 808 (1993), S/25704, 3 May 1993, paras. 29 and 33.

${ }^{46}$ Ibíd., para. 34.

${ }^{47}$ William Schabas, The UN International Criminal Tribunals: The Former Yugoslavia, Rwanda and Sierra Leone (Cambridge University Press, Cambridge, 2006), p. 61.

${ }^{48}$ Report of the Secretary General Pursuant to Paragraph 5 of Security Council Resolution 955 (1994) 13 February 1995, UN. Doc. S/1995/134, para. 12.

${ }^{49}$ Ibid.
} 
the first time criminalizes common article 3 of the four Geneva Conventions. ${ }^{, 50}$ Notably, the report omitted to mention that Rwanda was a party to Additional Protocol II and failed to explore whether Rwandan law had made violations of Additional Protocol II punishable, which might have helped to alleviate legality concerns. ${ }^{51}$ Nevertheless, the Secretary General's 'expansive approach' received approval from a United Nations Commission of Inquiry, which noted that:

significantly, no member of the Security Council opposed the Secretary-General's proposal, demonstrating consensus on the need to make headway in the legal regulation of internal conflict and to criminalize deviations from the applicable law. ${ }^{52}$

Thus, as at Nuremberg, the principle of legality was placed to one side in the interests of the greater goal of the development of ICL.

Unease concerning the ad hoc tribunals' compliance with the principle of nonretroactivity remained an issue once the tribunals began the task of applying and interpreting their Statutes in the cases coming before them. The Statutes provided the tribunals with a minimal framework as to the crimes over which they had jurisdiction, meaning that as a matter of necessity the tribunals had to make frequent reference to customary international law. Customary international law is by its very nature unwritten and difficult to decipher. A court can take a variety of sources into account when determining whether or not a customary norm exists: treaties; resolutions of international organisations such as the UN; documents from national organisations, such as army manuals; case law from domestic and international courts, for example. There is no precise formula or method as to how to determine whether or not a customary norm has emerged, the relative weight to be given to each element of evidence and how to balance and establish the two constituent elements of opinio juris and state practice. ${ }^{53}$

The reality of the need for ICCTs to rely on customary international law has been that: far from being able to call upon a vast and clearly defined corpus of customary law international law which imitatively defines the scope and nature of these offences...the judgments of the $a d$ hoc Tribunals frequently appear instead to be largely declaratory of nascent and previously unexpressed customary principles. ${ }^{54}$

Rather than customary international law acting as a restraint upon the judges of the court, as would appear to have been the original intention, the lack of certainty surrounding the identification of customary norms allowed judges at the ad hoc tribunals to interpret the law dynamically.

\footnotetext{
${ }^{50}$ Ibid. However, the Secretary General did note that, while the question of whether common article 3 entails criminal responsibility remains debatable, some of the crimes committed therein against a civilian population constituted crimes against humanity, which are customarily recognised as entailing the criminal responsibility of the accused, ibid, note 8.

${ }^{51}$ See Prosecutor v. Tadić, IT-94-1, Decision on the Defence Motion for Interlocutory Appeal on Jurisdiction, Appeal Chamber, 2 October 1995, paras. 132-135.

${ }^{52}$ Report of the International Commission of Inquiry on Darfur to the United Nations Secretary-General, pursuant to Security Council Resolution 1564, 18 September 2004, Geneva, 25 January 2005, para. 160. And see Schabas, supra note 47, p. 62.

${ }^{53}$ Dov Jacobs, 'International Criminal Law' in Jörg Kammerhofer and Jean D'Aspremont (Editors), International Legal Positivism in a Post-Modern World (Cambridge University Press, Cambridge, 2014), pp. 458-459.

${ }^{54}$ Susan Lamb, 'Nullum Crimen, Nulla Poena Sine Lege in International Criminal Law' in Antonio Cassese et al (Editors), The Rome Statute of the International Criminal Court: A Commentary, Volume 2, (Cambridge University Press, Cambridge, 2002), p. 745.
} 
As a consequence, the jurisprudence of the ad hoc tribunals is replete with examples where it can be argued that law has been applied retroactively, and that the judges of the tribunal have engaged in judicial law-making. One frequently referenced example of this is from the seminal Tadic case, where the ICTY considered whether the ICTY had jurisdiction over violations of IHL other than grave breaches of the Geneva Conventions under Article 3 of its Statute. It held that Article 3 gave the court jurisdiction over all 'serious violations' of IHL, whether committed in international or internal armed conflicts. ${ }^{55}$ Other examples include the ICTY's finding that customary international law does not require that crimes against humanity be committed during an armed conflict ${ }^{56}$ and the finding that the doctrine of joint criminal enterprise (JCE) constituted customary international law. ${ }^{57}$ Whilst these decisions raised the murky head of retroactive law, it was invariably refuted by the tribunal. The tribunal's decision would, in turn, be re-affirmed by references to its own case law over a series of cases, giving greater legitimacy to its findings.

Admittedly, this strategy has not always been successful. In the Kupreškić et al case, for example, the Trial Chamber of the ICTY held that reprisals against civilians were prohibited under customary law. ${ }^{58}$ Although there was opinio juris to support the Chamber's conclusion, there was little state practice, and the finding attracted some fierce criticism from commentators. ${ }^{59}$ Tellingly, the Chamber's decision has yet to be followed elsewhere, raising doubts as to whether the conclusion reached by the Chamber was in fact declaratory of customary international law.

It is not only the ad hoc tribunals that have garnered criticism that they have engaged in retrospective law-making, decisions from other ICCTs have also raised eyebrows. Examples include the Special Tribunal for Lebanon's finding of an international crime of terrorism under customary international law $^{60}$ and that this did not compromise the principle

\footnotetext{
${ }^{55}$ Prosecutor v. Tadić, Decision on the Defence Motion for Interlocutory Appeal on Jurisdiction, 2 October 1995, paras. 87-136. See Christopher Greenwood, 'International Law and the Tadić Case', 7 European Journal of International Law (1998), 265-283 and van Schaak, supra note 30, pp. 150-152.

${ }^{56}$ Tadić Appeal Decision, ibid., para. 141. The connection between crimes against humanity and armed conflict had already been severed in the Statute of the International Criminal Tribunal for Rwanda, although curiously this was not referred to by the Appeals Chamber in the Tadić case, see William A. Schabas, 'Interpreting the Statutes of the Ad Hoc Tribunals' in L.C. Vohrah et al (editors), Man's Inhumanity to Man: Essays on International Law in Honour of Antonio Cassese (Brill, Nijhoff, Leiden, 2003), pp. 870-871.

${ }^{57}$ Prosecutor v. Tadić, IT-94-1-1, Appeal Judgment, 15 July 1999, paras. 185-237. Legality concerns are particularly acute concerning the third category of JCE, where the Tadić Appeals Chamber relied mainly upon two post World-War cases to argue that this form of JCE was customary international law, see Steven Powles, 'Joint Criminal Enterprise: Criminal liability by prosecutorial ingenuity and judicial creativity?' 2 Journal of International Criminal Justice 606 (2004), pp. 615-616.

${ }^{58}$ Prosecutor v. Kupreškić et al, IT-95-16-T, Trial Judgment, 14 January 2000, paras. 527-536. Also see Prosecutor v. Milan Martić, IT-95-11-R61, Judgment, 8 March 1996, paras. 16-17.

${ }^{59}$ See for example, Christopher J. Greenwood, 'Belligerent Reprisals in the Jurisprudence of the International Criminal Tribunal for the Former Yugoslavia' in Fischer et al (eds.), International and National Prosecution of Crimes under International Law, Current Developments (Anro Spitz, Berlin, 2001), pp. 539-557 and F. Kalshoven, 'Two recent decisions of the Yugoslavia Tribunal in Vohrah et al, supra note 57, pp. 481-509.

${ }^{60}$ Interlocutory Decision in the Applicable Law: Terrorism, Conspiracy, Homicide, Perpetration, Cumulative Charging, Ayyash et al, STL-11-01/I/AC/R176bis, AC, STL, paras. $42-44$ and 83-113. Although the tribunal stated that it would apply the crime of terrorism as defined by Lebanese law, it interpreted it by reference to the international crime of terrorism which the tribunal had identified as constituting customary international law. However, a prohibition against terrorism under domestic law does not necessarily mean that it was reasonably foreseeable to an accused that they were committing a crime of international terrorism, as Saul explains 'it was hardly foreseeable to a person in Lebanon in 2005 that terrorism as such was an international customary-law crime
} 
of legality. ${ }^{61}$ The Special Court for Sierra Leone also stretched the principle of nonretroactivity with its decision that it was customary international law in 1996 that individual criminal responsibility was incurred for 'recruiting' children under fifteen, ${ }^{62}$ despite this being prior to the drafting of the ICC Statute, the first international instrument to specify the conduct as being a crime. ${ }^{63}$

With the advent of the International Criminal Court (ICC), together with its comprehensive Statute, ${ }^{64}$ it was hoped that the court would better comply with the principle of non-retroactivity. The Statute and its accompanying Elements of Crimes lay down an exhaustive list detailing the crimes over which the court has jurisdiction. Although customary international law is not listed as a primary source of law within Article 21 of the Statute, the provision listing the applicable law for the ICC, it has nevertheless been found to have a role to play in its interpretation. ${ }^{65}$ The principle of nulla crimen sine lege is specifically incorporated within the Statute. ${ }^{66}$ The ICC's more codified regime means that allegations of non-retroactivity will be harder to sustain, although as shall be seen shortly, this does not mean that the ICC system has satisfactorily resolved all legality issues.

or that such crime would be used ostensibly in 'interpreting' domestic offences but, in reality, to import a wholly new offence.' See Ben Saul, 'Legislating from a Radical Hague: The United Nations Special Tribunal for Lebanon Invents an International Crime of Transnational Terrorism', 24(3) Leiden Journal of International Law (2011) 677-700, p. 699.

${ }^{61}$ Ibid., paras. 131-148.

${ }^{62}$ Norman, SCSL-2004-14-AR72(E), Decision on Preliminary Motion Based on Lack of Jurisdiction (Child Recruitment), Appeal Chamber, 31 May 2004, para. 53. Notably, the Majority referred to the 'recruitment' of child soldiers throughout the judgment, when what the case concerned was the particular crime of enlistment. In his dissenting judgment, Justice Robertson distinguished between the distinct crimes of conscription, enlistment and use of children under fifteen to actively participate in hostilities (Ibid, Dissenting Opinion of Justice Robertson, para. 5). He noted that the crime under consideration was that of enlistment, and after careful consideration concluded that by the end of 1996 there was no customary rule imposing individual criminal responsibility for enlisting volunteers under the age of fifteen. Ibid. para.33 and see paras. 11-32. Also see Julie McBride, The War Crime of Child Soldier Recruitment, (Springer, Cham, 2014) pp. 95-96.

${ }^{63}$ Articles 8(2)(b)(xxvi) and 8(2)(e)(vii), ICC Statute.

${ }^{64}$ The strategy of having such a comprehensive statute has had both its proponents and its detractors. At the time of the Rome Diplomatic Conference, for example, the President of the European Court of Human Rights, President Rudolf Bernhart urged that the jurisdiction of the court 'be clearly defined in order to achieve the full effect of deterrence, avoid any doubts as to jurisdiction and ensure respect for the principle of legality'. UN. Doc. A/CONF.183/SR.3 16 June 1998, p. 79. Others have argued that the ICC regime is over-codified, risking stultifying further growth in the law, see The Hon. David Hunt, "High Hopes, "Creative Ambiguity" and an Unfortunate Mistrust in International Judges', 2 Journal of International Criminal Justice (2004) 56-70, p. 59, and see Alain Pellet, 'Applicable Law' in Antonio Cassese et al (eds.), The Rome Statute of the International Criminal Court: A Commentary, Vol. II (Oxford University Press, Oxford, 2002), p. 1053 and Joseph Powderly, 'The Rome Statute and the Attempted Corseting of the Interpretative Judicial Function: Reflections on Sources of Law and Interpretative Technique', Carsten Stahn (ed.), The Law and Practice of the International Criminal Court, (Oxford University Press, 2015). For the impact of the Statute on existing or developing international law see Article 10, ICC Statute and see Aldo Zammit Borda, 'The Direct and Indirect Approaches to Precedent in International Criminal Courts and Tribunals', 14 Melbourne Journal of International Law 608 (2013).

${ }^{65}$ Article 21, ICC Statute and see Larissa van den Herik, 'The decline of customary international law as a source of international criminal law', Grotius Centre Working Paper, 2014/038-ICL and Alessandro Bufalini, 'The Principle of Legality and the Role of Customary International Law in the Interpretation of the ICC Statute' 14 The Law and Practice of International Courts and Tribunals (2013) 233-254.

${ }^{66}$ Article 22 provides: ' 1 . A person shall not be criminally responsible under this Statute unless the conduct in question constitutes, at the time it takes place, a crime within the jurisdiction of the Court.

2. The definition of a crime shall be strictly construed and shall not be extended by analogy. In case of ambiguity, the definition shall be interpreted in favour of the person being investigated, prosecuted or convicted. 3 . This article shall not affect the characterization of any conduct as criminal under international law independently of this Statute.' Also see Articles 23 and 24. 
ICL is therefore replete with occasions where it is possible to argue that the prohibition against retroactive application of the law has been violated. However, it is no longer plausible for new categories of crimes to be created retroactively in the way that they were following the Second World War. The post-World War Two tribunals and the ad hoc tribunals have played their part in outlining the basic substantive crimes of ICL. Gallant writes of common law legal systems that:

Within the common law system as a whole, the era of wholesale crime creation, in which courts rather than legislatures created the major common law felonies (e.g., murder, robbery, rape), is over. ${ }^{67}$

This sentiment has certain parallels to the formation period of ICL. While ICCTs may not have been guilty of 'wholesale' crime creation, as they are each bound by a statute spelling out their jurisdiction, arguably the same basic premise applies. Due to the insufficiency of detail within their Statutes, ICCTs have by necessity had to turn to customary and conventional law in order to fill the gaps and to fulfil their mandate. ICL has now reached a stage in its development where there is no longer room for claims of 'substantive justice' or for applying natural law perspectives ${ }^{68}$ over the principle of legality.

At the ICC, the trend is towards less reliance upon customary international law than has been the case before the ad hoc tribunals. ${ }^{69}$ This is to be welcomed. Nevertheless, customary international law continues to have a part to play before the ICC and can be relied upon in the event that there is a lacuna within the Statute. ${ }^{70}$ The court should resort to customary international law with caution, bearing in mind that its role is to determine the guilt or innocence of the accused in a manner that is fair and impartial, rather than to progressively develop the law. ${ }^{71}$

\section{The Doctrine of Specificity}

ICL has proved unable to comply rigidly with the specificity aspect of the legality doctrine. The difficulties begin within the statutes of the different ICCTs. Some provisions reference other treaties, for example the grave breach provisions of the Geneva Conventions ${ }^{72}$ or their Common Article $3 .^{73}$ These treaties are not ICL treaties and were not drafted with individual criminal responsibility in mind, rather they are the result of negotiations and compromises between states. Furthermore, they were drafted by diplomats rather than experts in the field of ICL ${ }^{74}$ meaning that they often contain broad, open-ended wording, which does not

\footnotetext{
${ }^{67}$ Gallant, supra note 8, p. 35.

${ }^{68}$ Prosecutor v. Kupreškić et al, IT-95-16-T, Trial Judgment, 14 January 2000, para. 527.

${ }^{69}$ Van den Herik, supra note 65.

${ }^{70}$ For example, see The Prosecutor v. Omar Hassan Ahmad Al Bashir, ICC-02/05-01/09, Pre-Trial Chamber I, Decision on the Prosecution's Application for a Warrant of Arrest against Omar Hassan Ahmad Al Bashir, 4 March 2009, para. 44; Prosecutor v. Thomas Lubanga Dyilo, ICC-01/04-01/06-772 and Judgment on the Appeal of Mr. Thomas Lubanga Dyilo against the Decision on the Defence Challenge to the Jurisdiction of the Court pursuant to article 19(2)(a) of the Statute of 3 October 2006, 14 December 2006.

71 Jacobs, supra note 53, p. 473.

${ }^{72}$ Article 2, ICTY Statute, Article 8(2)(a), ICC Statute and see Bassiouni, supra note 8, pp. 96-97.

${ }^{73}$ Article 4, ICTR Statute and Article 8(2)(c), ICC Statute.

${ }^{74}$ Van Schaak, supra note 30, p. 135.
} 
necessarily transfer easily into the field of ICL. ${ }^{75}$ The need for ICCTs to refer to customary international law also causes difficulties as regards to the adherence to the requirement of specificity, due to the dynamic and unclear nature of that body of law.

Several substantive crimes have been challenged on the grounds that they are insufficiently specific. At the ICTY for example, the category of 'other inhumane acts' as a crime against humanity ${ }^{76}$ was criticised for lacking clarity and permitting punishment by analogy. Thus, in the Kupreškić case, the Trial Chamber noted that 'There is a concern that this category lacks precision and is too general to provide a safe yardstick for the work of the Tribunal and hence, that it is contrary to the principle of the "specificity" of ICL." 77

Nevertheless, the Chamber acknowledged the utility of not exhaustively defining the crime, noting that 'An exhaustive categorization would merely create opportunities for evasion of the letter of the prohibition. ${ }^{78}$

Other provisions have also been criticised for being too open textured. In the case of Čelebici $i$, the defence argued that the offences of causing 'great suffering or injury' and of 'wilfully causing great suffering or serious injury to body or health' and 'inhuman treatment' lacked the specificity required for criminal statutes and could not, therefore, form the basis of a criminal prosecution. ${ }^{79}$ This argument was rejected by the Trial Chamber which found that the terms could be defined by reference to the Geneva Conventions and their Commentaries, having regard to how the terms had been interpreted by other international adjudicative bodies. ${ }^{80}$

A rare example of a successful challenge on the grounds of specificity can be found in the case of Vasiljevic from the ICTY. The accused was charged with 'violence to life and person' as a war crime under Article 3 of the ICTY Statute, founded on common Article 3 of the Geneva Conventions. When considering the proposed war crime, the Trial Chamber stated that it must be satisfied that a certain act was indeed criminal under customary international law, and that it was defined with sufficient clarity under customary international law for its general nature, its criminal character and its approximate gravity to have been sufficiently foreseeable and accessible. When making the assessment, the Trial Chamber stated that it 'takes into account the specificity of international law, in particular that of customary international law. ${ }^{81}$ The Chamber held that there was no clear indication in the practice of states as to what the definition of the offence of 'violence to life and person' may be under customary international law and was not satisfied that such an offence gave rise to individual criminal responsibility. ${ }^{82}$

\footnotetext{
${ }^{75}$ Rogier Bartels, 'Discrepancies between international humanitarian law on the battlefield and in the courtroom: The challenges of applying international humanitarian law during international criminal trials', M. Matthee et al (eds.), Armed Conflict and International Law: In search of the human face (T.M.C. Asser Press, The Hague, 2013), 339-378, p. 344.

${ }^{76}$ Article 6(c), Nuremberg Charter; Article 5(i), ICTY Statute and Article 3(i), ICTR Statute.

${ }_{77}$ Prosecutor v. Kupreškić et al, (IT-95-16-T), Judgment, 14 January 2000, para. 563.

${ }^{78}$ Kupreškić et al, para. 563.

${ }^{79}$ Prosecutor v. Delalić, Mucić, Delić and Landžo, case no. IT-96-21-T, Judgment, paras. 503 and 515.

${ }^{80} \mathrm{Ibid}$.

${ }^{81}$ Prosecutor v. Vasiljević, IT-98-32-T, 29 November 2002, para. 201. Also see Van Schaak, supra note 30, pp. 139-140.

${ }^{82}$ Vasiljevic, ibid, para. 203. Also see the case of Ntakirutimana where the Trial Chamber expressed doubts concerning the 'lack of clarity' of the provision. Prosecutor v. Ntakirutimana, ICTR-96-10 and ICTR-96-17-T Trial Judgment, 21 February 2003, para. 861. For a discussion of the Vasiljević case see Joanna Dingwall,
} 
The ICC Statute is not immune from the accusation that parts of the substantive crimes lack specificity. ${ }^{83}$ Although the drafters took great pains to precisely define the offences in the Statute and the accompanying Elements of Crimes, reference is nevertheless made to some residual definitions. Thus, the war crimes of committing 'outrages upon personal dignity ${ }^{94}$, and that of committing 'any other form of sexual violence ${ }^{85}$ can be criticised from this perspective. The category of 'other inhumane acts' as a crime against humanity is also included within the ICC Statute, and has been critiqued by scholars for violating the principle of specificity, despite the Statute stating that the acts must be 'of a similar character intentionally causing great suffering, or serious injury to body or to mental or physical health. ${ }^{86}$ In addition, the Statute refers to normative elements, such as 'armed conflict', 'protected person', 'attack', 'military objective' and 'military necessity'. ${ }^{87}$ These expressions are not further defined in the Elements of Crimes, meaning that the ICC has had to look to other sources, such as international humanitarian law and customary law, as reflected in the case law of the ad hoc tribunals, in order to define them. ${ }^{88}$ When making reference to other bodies of law to clarify and interpret ICL, ICTs must bear in mind that other areas of international law have different objectives which may conflict with those of ICL. ${ }^{89}$ Providing that the particularities of ICL are borne in mind however, using other sources of law to interpret terms is not at odds with the principle of legality.

It is important to remember that the challenges of adhering to the principle of specificity are not unique to ICL, similar challenges also face domestic legal systems. ${ }^{90}$ It is impossible to completely clarify every element of behaviour that is prohibited by law and cater for every situation which may arise. ${ }^{91}$ There needs to be some flexibility and leeway for interpretation, and some room for manoeuvre left. ICCTs have acknowledged this. The ICTY has held that the principle of legality 'does not prevent a court, either at the national or international level, from determining an issue through the process of interpretation and

\footnotetext{
'Unlawful Confinement as a War Crime: The Jurisprudence of the Yugoslav Tribunal and the Common Core of International Humanitarian Law Applicable to Contemporary Armed Conflicts', Vol. 9(2) Journal of Conflict and Security Law (2004) 133-179.

${ }^{83}$ Fletcher and Ohlin, supra note 11, p. 551.

${ }^{84}$ Article 8(2)(b)(xxi), ICC Statute. The Elements of Crimes defines the crime as the perpetrator humiliated, degraded or otherwise violated the dignity of one or more persons and the severity of the humiliation, degradation or other violations was of such a degree as to be generally recognised as an outrage upon personal dignity.

${ }^{85}$ Article 8(2)(b)(xxii), ICC Statute. In international armed conflicts, the Elements of Crimes state that the conduct must be of a gravity comparable to that of the Geneva Conventions. Whereas for the equivalent provision in noninternational armed conflicts, Article 8(2)(e)(vi), the Elements provide that the conduct must be of a gravity comparable to that of a serious violation of common Article 3 to the four Geneva Conventions.

${ }^{86}$ Article 7(1)(k), ICC Statute. 'Article 7(1)k) of the ICC Statute refers to "other inhumane acts of a similar character, which is a classic example of punishment by analogy in contradiction to the lex stricta requirement under Article 22(2) of the ICC Statute.' Kai Ambos, 'Remarks on the General Part of International Criminal Law' 4 Journal of International Criminal Justice 660-673 (2006) at p. 670. Also see Fletcher and Ohlin, supra note 11, p. 551.

${ }^{87}$ Héctor Olásolo, 'A Note on the Evolution of the Principle of Legality in International Criminal Law', 18 Criminal Law Forum (2007) 301-319, pp.310-311.

${ }^{88}$ See Bartels, supra note 75.

${ }^{89}$ See the discussion of the in dubio pro reo principle, below and Bartels, supra note 75 . For an analysis of the impact of ICL on IHL see Shane Darcy, Judges, Law and War: The Judicial Development of International

Humanitarian Law, (Cambridge University Press, Cambridge, 2014).

${ }^{90}$ Bassiouni, supra note 8, pp. 95-96 and 76-85.

${ }^{91}$ Arajärvi, supra note 3, p. 16.
} 
clarification as to the elements of a particular crime. ${ }^{92}$ A similar attitude has been adopted by the ECtHR, which has held that the Convention cannot be read as outlawing the gradual clarification of the rules of judicial interpretation from case to case, provided that the resultant development is consistent with the essence of the offence and could reasonably be foreseen. ${ }^{93}$

\section{The Doctrine of Foreseeability}

Another dimension of legality is the doctrine of foreseeability. This has caused conflict within ICL firstly, as regards the foreseeability of prosecution before an ICCT at all, and secondly, as regards the foreseeability of prosecution for certain crimes.

To date, with the exception of the ICC,${ }^{94}$ all ICCTs were created after the events over which they have jurisdiction took place. Objections on the grounds of retroactivity ${ }^{95}$ have been countered with the argument that the deeds that had been committed were so wrong and so clearly criminal that the perpetrators must have known that what they were doing was wrong. Luban, for example, writes in the context of the IMT that:

when the deed is morally outrageous...then no reasonable expectations of the defendants are violated when they are tried for it. The Nazi leadership, with the blood of 50 million people on their hands, fully expected summary execution if they were defeated. ${ }^{96}$

Others have queried whether fair notice was adequate in the context of the armed conflict in the former Yugoslavia. May, for example, objects to the 'plight of some of the Bosnian Serb "small fry" now in jail at The Hague who had no hint that their acts, as unspeakable as they may be, were even remotely likely to land them in jail awaiting trial before an international tribunal. ${ }^{97}$ While the behaviour was likely criminal under domestic law, is this sufficient fair notice for the accused that the same behaviour constitutes a crime under international law? International crimes have a different character to domestic crimes, as Doherty and McCormack explain:

domestic penal provisions fail to capture what makes the international crimes truly heinous and distinguishes them from domestic "equivalents". What gives the acts listed their dubious status as international crimes is the additional element- the context or "situationing" for crimes against humanity and the mental element for genocide. ${ }^{98}$

Criminalisation of certain behaviour at a domestic level does not necessarily make it foreseeable that the same behaviour might be prosecuted as a different international crime.

\footnotetext{
${ }^{92}$ Prosecutor v. Aleksovski, IT-95-14/1-A Appeals Chamber, 24 March 2000, para. 127. Also see Prosecutor v. Milutinović and others, IT-99-37-AR72, Decision on Dragoljub Ojdanić's Motion Challenging Jurisdiction- Joint Criminal Enterprise, 21 May 2003, paras. 37-38, and Mohamed Shahabuddeen, 'Does the Principle of Legality Stand in the Way of Progressive Development of the Law?', 2(4) Journal of International Criminal Justice (2004) 1007.

${ }^{93}$ S.W. v. The United Kingdom, Application no. 20166/92, 22 November 1995, para. 36.

94 'No person shall be criminally responsible under this Statute for conduct prior to the entry into force of the Statute.' Article 24(1), ICC Statute.

${ }^{95}$ Gallant, supra note 8, p. 40.

${ }^{96}$ Luban, supra note 12 p. 20.

${ }^{97}$ Larry May, Crimes against Humanity: A Normative Account (Cambridge University Press, Cambridge 2005), p. 109. While the behaviour

${ }^{98}$ Katherine L. Doherty and Timothy L.H. McCormack, "“Complementarity” as a catalyst for comprehensive domestic penal legislation' 5 University of California, Davis Journal of International Law and Policy 147 (1999), pp. 166-167.
} 
Although the legal status of ICCTs has been challenged, these challenges have not been directly founded on the basis of the principle of legality. ${ }^{99}$ The ICTY's formation, for example, was disputed on the basis of whether the Security Council had the power to create such an entity, and whether the establishment of the tribunal was contrary to the general principle whereby courts must be 'established by law' 100 as required by human rights law. Regarding the foreseeability of prosecution before an ICCT, Jacobs argues that

In international law, the standard situation is usually the absence of enforcement mechanisms and, therefore, the absence of prosecution for the commission of international crimes is foreseeable. As a consequence, the international prosecution of international crimes can only be foreseeable if there is already a tribunal with jurisdiction over the facts in existence. ${ }^{101}$ Jacobs' view is that this applies regardless of the recent increase in number of international tribunals. ${ }^{102}$ This author would dispute this position, however. Over the past two decades or so, the field of international criminal justice has become an integral part of international law, and at least for those who are in positions of leadership, it is arguably foreseeable that they may be held accountable for their actions at some point in the future, regardless of the lack of existence of a specific court at the time any alleged crimes occurred. While this may not necessarily apply concerning historical crimes from the pre-ICC era, there is a strong case to be made that it applies as regards crimes committed following the entry into force of the ICC Statute, whether or not the alleged crimes fall within the ICC's jurisdiction.

The need for ICCTs to have recourse to customary international law has caused difficulties regarding the foreseeability of prosecution concerning particular crimes. If judges from ICCTs spend pages of their judgments analysing whether there is sufficient state practice and opinio juris to establish that a customary norm has formed, it seems a fair stretch to argue that an alleged perpetrator could have been aware that their prosecution for the offence was foreseeable. ${ }^{103}$ Nevertheless, the ICTY has held that customary international law does provide sufficient guidance as to the standard the violation of which could entail criminal liability. ${ }^{104}$ The ICTY has adopted a wide test concerning foreseeability. In Hadžihasanović, the Appeals Chamber held that 'As to foreseeability, the conduct in question is the concrete conduct of the accused; he must be able to appreciate that the conduct is criminal in the sense generally understood, without reference to any specific decision.' ${ }^{105}$ The lack of a requirement to tie the conduct to a specific decision is seemingly at odds with the requirements of legality. Legality

\footnotetext{
${ }^{99}$ At the SCSL and the STL the challenge was founded partly on the constitutionality of the tribunals, see Prosecutor v. Kallon, Norman, Kamara, SCSL-2004-15-AR72(E) SCSL-2004-14-AR72(E), SCSL-2004-16AR72(E), Appeals Chamber Decision on Constitutionality and Lack of Jurisdiction, 13 March 2004 and Prosecutor v. Salim Jamil Ayyash et al, STL-11-01/PT/TC, Decision on the Defence Challenges to the Jurisdiction and Legality of the Tribunal, Trial Chamber, 27 July 2012.

${ }^{100}$ Tadić Decision, supra note 55, para 41 et seq. Also see the separate opinion of Judge Sidhwa who rejected the argument that the ICTY should not have been granted power to retrospectively punish crimes, stating 'all "wouldbe" accused were on notice, through Resolutions of the Security Council, to refrain from committing such crimes.' Prosecutor v. Tadić, Separate Opinion of Judge Sidhwa on the Defence Motion for Interlocutory Appeal on Jurisdiction, 2 October 1995, para. 72.

101 Jacobs, supra note 53, p. 461.

102 Ibid., pp. 461-462.

103 Jacobs, supra note 53, p. 466.

${ }^{104}$ Prosecutor v. Milutinović (Milan) and others, IT-99-37-AR72, Decision on Dragoljub Ojdanić's Preliminary Motion to Dismiss for Lack of Jurisdiction- Joint Criminal Enterprise, 21 May 2003, para. 41.

105 Prosecutor v. Hadžihasanović et al, IT-01-47-AR72, Decision on Interlocutory Appeal Challenging Jurisdiction in Relation to Command Responsibility, 16 July 2003, para. 34.
} 
requires certainty in the law, and not reference to conduct which is "criminal in the sense generally understood'. ${ }^{106}$ A better reference point can be taken from the ECtHR, which has determined that in order to comply with the terms of Article 7 'an offence must be clearly defined in the law'107 and that this is satisfied 'where the individual can know from the wording of the relevant provision, and if need be, with the assistance of the courts' interpretation of it, what acts and omissions will make him criminally liable. ${ }^{108}$ The gradual clarification of the rules of criminal liability through judicial interpretation does not contravene Article 7, provided it is consistent with the essence of the offence and could reasonably be foreseen. ${ }^{109}$ If the behaviour in question is aimed at 'human dignity and human freedom' or where it violates the right to life ${ }^{110}$ the court has adopted 'reasonably foreseeable' and 'accessible tests'. ${ }^{111}$ While judicial interpretation of the law may not necessarily be at odds with legality, the ECtHR's approach requires that there be a law in existence to begin with, rather than the ICTY's vague direction that the 'conduct is criminal in the sense generally understood'.

\section{The Doctrine of Strict Construction}

The final element of the principle of legality to be examined for the purposes of this paper, is that which requires that penal statutes be construed strictly. This is linked to the principle of in dubio pro reo, that crimes should be interpreted in favour of the accused. The ICTY has held that the principle does not prevent it from creatively interpreting the rules. Thus, in the case of Čelebić $i$ the Trial Chamber noted that:

(t)he rule of strict construction requires that the language of a particular provision shall be construed such that no cases shall be held to fall within it which do not fall both within the reasonable meaning of its terms and within the spirit and scope of the enactment. ${ }^{12}$

It continued that:

The rule of strict construction is not violated by giving the expression its full meaning or the alternative meaning which is more consonant with the legislative intent and best effectuates such intent. The effect of strict construction of the provisions of a criminal statute is that where an equivocal word or ambiguous sentence leaves a reasonable doubt of its meaning which the canons of construction fail to solve, the benefit of the doubt should be given to the subject and against the legislature which has failed to explain itself. This is why ambiguous criminal statutes are to be construed contra proferentem. ${ }^{113}$

Consequently, there are few examples of the principle of strict construction being applied in ICL. One exception is that of Akayesu, which concerned the interpretation of Article 2(2)(a)

\footnotetext{
106 Jacobs, supra note 53, p. 462.

${ }^{107}$ Kokkinakis v Greece, Application no. 14307/88, 25 May 1993, para. 52.

108 Ibid.

${ }^{109}$ CR v. The United Kingdom, Application no. 20190/92, 22 November 1995, para. 34.

${ }^{110}$ See the spousal rape cases, CR v. The United Kingdom, Application no. 20190/92, 22 November 1995, para. 42 and S.W. v. The United Kingdom, Application no, 20166/92, 22 November 1995, para. 44.

${ }^{111}$ CR v. The United Kingdom, ibid., para. 34; S.W. v. The United Kingdom, ibid., para. 36; Kononov v. Latvia, App. No. 36376/04, 17 May 2010, para. 236.

${ }^{112}$ Delalić et al, supra note 79, para. 410.

${ }^{113}$ Ibid, paras. 412-413.
} 
of the ICTR Statute concerning killing members of a group as an act of genocide. The English version of the Statute refers to 'killing'. The Trial Chamber found this term to be too general, possibly including intentional and unintentional genocides. The French version of the text referred to 'meurtre', which the Chamber found to be more precise, requiring an intention to commit the act. This understanding was also found to be more in accordance with the definition of homicide in the Penal Code of Rwanda. ${ }^{114}$ The Chamber held that ' $(\mathrm{g})$ iven the presumption of innocence of the accused, and pursuant to the general principles of criminal law, the Chamber holds that the version more favourable to the accused should be upheld'. Accordingly, the French version was adopted. ${ }^{115}$

ICCTs have applied the principle of strict construction not only as regards the interpretation of the substantive law, but also concerning other aspects of international criminal trials. ${ }^{116}$ For example, it has been applied by the ICTY in relation to the interpretation of evidence. In IHL, in cases of doubt whether a person is a civilian, there is a presumption favour of that person being a civilian. ${ }^{117}$ In the Galic case, the ICTY held that when determining whether or not an alleged victim had been a civilian or not for the purposes of a charge of directly attacking civilians, 'the Prosecution must show that in the given circumstances a reasonable person could not have believed that the individual he or she attacked was a combatant.' 118 Thus, the Trial Chamber effectively reversed the presumption in ICL in order to protect the rights of the accused.

The matter of whether the doctrine of strict construction applies only as to the substantive law or also to other areas is an issue at the ICC. Article 22(2) of its Statute requires that ' $(\mathrm{t})$ he definition of a crime shall be strictly construed and shall not be extended by analogy. In case of ambiguity, the definition shall be interpreted in favour of the person being investigated, prosecuted or convicted.' Judge van den Wyngaert has argued that the article applies also to modes of liability at the court. In the case of Chui she stated:

I attach the greatest importance to Article 22(2) of the Statute, which obliges the Court to interpret the definition of crimes strictly and prohibits any extension by analogy. There can be little doubt that this fundamental principle applies with equal force in relation to the definition of criminal responsibility. ${ }^{119}$

She argued Article 22(2) overrides the conventional methods of treaty interpretation, as defined in the Vienna Convention on the Law of Treaties stating:

Whereas these methods of interpretation may be entirely adequate for interpreting other parts of the Statute, I consider that for interpreting articles dealing with the criminal responsibility of individuals, the principles of strict construction and in dubio pro reo are paramount. ${ }^{120}$

\footnotetext{
${ }^{114}$ Prosecutor v. Akayesu, ICTR-96-4-T, 2 September 1998, para. 500. Also see Powderly, supra note 64, p. 492. 115 Ibid, para. 501.

${ }^{116}$ For a discussion of whether or not this is appropriate vis-à-vis the ICC Statute, see Powderly, supra note 64, pp. 494-496.

${ }^{117}$ Article 50(1), Protocol Additional to the Geneva Conventions of 12 August 1949, and Relating to the Protection of Victims of International Armed Conflicts, 1977.

118 Prosecutor v. Stanislav Galić, IT-98-29-T, Trial Judgment, 5 December 2003, para. 55. For a discussion of the in dubio pro reo principle and the presumption in favour of civilian status, see Nobuo Hayashi, 'The role of judges in identifying the status of combatants', 2 Acta Societatis Martensis (2006) 69-92.

${ }^{119}$ Prosecutor v. Mathieu Ngudjolo Chui, ICC-01/04-02/12-4, Judgment pursuant to Article 74 of the Statute, Concurring Opinion of Judge Christine Van den Wyngaert, 18 December 2012, para. 18.

${ }^{120}$ Ibid.
} 
However, as Werle and Burghardt explain, the principle of strict construction does not mean that the court is always to choose the most restrictive of all conceivable interpretations. Such an understanding would lead to unreasonable results and would rule out an evaluation of possible interpretations. Rather, the principle only takes effect when after an interpretation 'in accordance with the ordinary meaning to be given to the terms of the treaty in their context and in the light of its object and purpose, two equally plausible interpretations remain'. ${ }^{121}$

Such an interpretation of the principle of strict construction is consistent with the pattern within domestic systems, where the presumption of strict construction in favour of the accused is generally one of last resort, when other means of interpretation have been applied and have failed to resolve the issue. ${ }^{122}$

\section{Conclusion}

It is beyond question that ICL has had an awkward relationship with the principle of legality. From the IMT tribunal, where legality was set aside in favour of a doctrine of 'substantive justice', to the ad hoc tribunals adopting a 'relaxed approach', to the stricter version of legality found within the Statute of the ICC, ICL has applied the principle in a way that best suits its purposes and stage of development.

This 'soft' approach to legality has been tolerated in favour of the aim of progressing ICL to the detriment of the rights of the accused. ${ }^{123}$ Applying a relaxed approach to legality is no longer acceptable, indeed if it ever was. It is not tenable to argue that legality applies differently in ICL than it does in domestic criminal law. ${ }^{124}$ Both legal systems have the same premise at heart, that of holding individuals criminally liable for their actions. If ICL is to be effective in protecting the rights of the accused and ensuring that trials are fair and impartial, it is vital that more emphasis is placed upon the principle of legality. As Justice Robertson eloquently explains,

it is precisely when the acts are abhorrent and deeply shocking that the principle of legality must be strictly applied, to ensure that a defendant is not convicted out of disgust rather than evidence, or of a non-existent crime. Nullum crimen may not be a household phrase, but it serves as some protection against the lynch mob. ${ }^{125}$

The act of placing legality centre stage does not call a halt to the development of ICL. Legality is a reasonably pliant concept. It is a mistake to imagine that there is one pure,

\footnotetext{
${ }^{121}$ Gerhard Werle and Boris Burghardt, 'Do Crimes against Humanity require the participation of a state or a "state-like" organization?', 10 Journal of International Criminal Justice, (2012) 1151 at p. 1159. For the same authors' criticism of Judge Van den Wyngaert's argument in the context of Article 25(3) of the ICC Statute, see Gerhard Werle and Boris Burghardt, 'Modes of Participation in Article 25 of the ICC Statute' in Elies van Sliedregt and Sergey Vasiliev (eds.), Pluralism in International Criminal Law (Oxford University Press, Oxford, 2014), p. 314.

${ }^{122}$ Powderly, supra note 64, pp. 490-491.

${ }^{123}$ Schabas, for example, explains that 'Although formally professing rigid adherence to the nullum crimen principle, in practice judges at the ad hoc tribunals have taken a relatively relaxed approach, much in the spirit of their predecessors at Nuremberg, and in keeping with the liberal application adopted by the European Court of Human Rights.' William Schabas, The UN International Criminal Tribunals: The Former Yugoslavia, Rwanda and Sierra Leone (Cambridge University Press, Cambridge, 2006) pp. 155-156.

124 Jacobs, supra note 53, p. 472.

${ }^{125}$ Dissenting Opinion of Justice Robertson, supra note 62, para. 12.
} 
perfect model to aspire to: even most domestic systems do not live up to an ideal. Dubber writes:

It is an oversimplification to regard domestic criminal-law systems as grounded in legality, occasional slip-ups on the margins notwithstanding, and as closely approximating an ideal of legality that has so far remained beyond ICL's grasp. ${ }^{126}$

There is no gold standard of legality even within domestic law and legality allows for a certain amount of flexibility and interpretation.

ICCTs have a responsibility to set an example and to ensure that proceedings are fair to the accused. If they set low standards there is a danger that states follow suit, leading to a trickle-down effect. ${ }^{127}$ ICL should strive to show the world how justice should be done and seen to be done. If ICL is going to be an effective and legitimate legal system, it is important that it adopts a stricter view of legality than it has in the past and does not allow lex lata to be confused with lex ferenda.

There are positive signs that greater adherence is being paid to the principle of legality, not least its inclusion within the ICC statute. ICL has moved on from the days where claims of substantive justice can trump those of legality. It has also reached a stage whereby those who commit atrocities anywhere in the world cannot claim that their prosecution for these acts before an ICCT was not foreseeable. The basic substantive crimes which make up international criminal justice have been largely settled, but there is still room for interpretation and clarification of these crimes. As with domestic law, the application of ICL is never going to be a mechanical, one-size-fits-all affair. It requires a process of interpretation and subjectivity. ${ }^{128}$ The adoption of a codified system in the ICC Statute and the gradual maturation of the field means that the need to refer to customary international law is decreasing. The move away from reliance upon customary international law also has positive implications for the principle of legality.

As ICL moves into the future, it must place the rights of the accused centre stage if it is to be an effective and legitimate legal system. In achieving this, legality is a vital tool in its arsenal.

\footnotetext{
${ }^{126}$ Markus D. Dubber, 'Common Civility: The Culture of Alegality in International Criminal Law,' 24 Leiden Journal of International Law (2011) 923-936 at p. 928.

${ }^{127}$ Yvonne McDermott, Fairness in International Criminal Trials (Oxford University Press, Oxford, 2016), pp. 137-140.

${ }^{128}$ Powderly, supra note 64, p. 445.
} 